\title{
Teachers' Perceptions of Engagement and Effectiveness of School Community Partnerships: NASA's Online STEM Professional Development
}

\author{
Matthew J. Keil \\ Dept. of Teaching Learning and Culture Texas A\&M University \\ MS 4232 College Station, TX, 77843 USA \\ Tel: 1-979-845-8384 E-mail:sscoobydoo4@neo.tamu.edu
}

William H. Rupley (corresponding author)

Dept. of Teaching Learning and Culture Texas A\&M University

MS 4232 College Station, TX, 77843 USA

Tel: 1-979-845-8384 E-mail: w-rupley@tamu.edu

Janet A. Nichols

Department of Teacher and Counselor Education, The University of Maine MS 5749 Merrill Hall Orono, ME, 04469 USA

Tel: 1-207 581-3117_E-mail: janet.nichols@maine.edu

\begin{abstract}
William Dee Nichols
Department of Teacher and Counselor Education, The University of Maine

MS 5749 Merrill HallOrono, ME, 04469 USA
\end{abstract}

Tel: 1-207 581-3117_E-mail: william.nichols1@maine.edu 
David Paige

\author{
Annsley Frazier Thornton School of Education \\ Bellarmine University 2001 Newburg Road Louisville, KY 40205 \\ Tel: 502-272-8153Ｅ-mail: dpaige@bellarmine.edu
}

\author{
Timothy V. Rasinski \\ Kent State University
}

White Hall 401 Kent, OH 44242

Tel: 330-672-2580 E-mail: trasinski@kent.edu

Received: Jan 17, 2016 Accepted: March 22, 2016 Published: May 1, 2016

doi:10.5296/jse.v6i2.9185 URL: http://dx.doi.org/10.5296/jse.v6i2.9185

\begin{abstract}
Data were collected from 32 teachers using mixed methods to investigate their perceptions of the value of online professional development (PD) offered through a school-community partnership with National Aeronautics and Space Administration (NASA). The partnership between multiple school districts nationwide and NASA provided teachers with an online Science, Technology, Engineering and Mathematics (STEM) PD course called MicroGX. Data from this study provide evidence that teachers perceived MicroGX as a positive PD experience. Teachers indicated that they would recommend this PD to other teachers, and overall were satisfied with interaction with others, resources, support, content, and content delivery. Effective PD components include building teachers' content knowledge, impacting students' learning, increasing teaching resources, and providing support for participation in PD.
\end{abstract}

Keywords: online professional development, STEM classroom education, professional development engagement, school community partnerships, STEM content knowledge 


\section{Need for Professional Development}

President Obama's Race to the Top encourages states to inform teachers about how they can improve their instruction (U.S. Department of Education, 2009). Thus, Educational leaders in K-12 public schools are charged with the implementation of effective professional development (PD); however, they are also challenged with inadequate funding and time to implement effective PD programs (Interactive Educational Systems Design, 2011).Advances in technology have allowed schools to take advantage of the benefits offered by online PD, which facilitates reduction in costs and enhancement of quality (Harlen \& Doubler, 2004).

\subsection{Benefits of Online Professional Development}

Online PD has allowed schools to benefit from free resources including face-to-face PD provided by their community (Interactive Education Systems Design, Inc., 2011). Implementation of online PD through school-community partnerships can allow educational leaders to reduce time and funding needed to develop and implement PD resources for their faculty. For the purpose of this study, a school-community partnership is defined as any formal arrangement between a school and community organization including federal, public, private, and commercial institutions or individuals for the purpose of providing a service or resource that will help support student achievement (Chadwick, 2004).

Existing research provides strong evidence that online learning communities are effective for PD (U.S. Department of Education, Office of Planning, Evaluation and Policy Development, 2010). The Center for Technology in Learning prepared an evaluation of evidence-based practices in online learning for the U.S. Department of Education, Office of Planning, Evaluation, and Policy Development (ED OPEPD). ED OPEPD's evaluation in a meta-analysis of online learning studies found that learning content in an on-line setting was more effective than learning the same content in a face-to-face setting (U.S. Department of Education, Office of Planning, Evaluation and Policy Development, 2010). Research offers further support that online learning communities for PD can reduce teacher isolation and support sharing, foster reflection on practice, influence teaching practice, and support formation of communities of practice (Barnett, 2002; Matusov, Hayes, \& Pluta, 2005). Other studies show no significant differences in learning when comparing online PD to face-to-face PD (Castle \& McGuire, 2010; Fisher, Schumaker, Culbertson, \& Deshler, 2010; Harlen \& Doubler, 2004; Schmidt, 2002), which further supports using online PD when both financial and time constraints are limited.

\subsubsection{PD Online with School Community Partnerships}

While there is ample research suggesting that online PD can replace face-to-face PD without jeopardizing effectiveness, there are few studies related to PD delivered online by school-community partnerships. Investigations focusing on the efficacy and features of school-community partnerships (Avalos, 2010; Lemke, 2012; Sandholtz, 2002) provide examples of using interviews and surveys with stakeholders and a qualitative analysis to identify common and emerging themes that contribute to the success of partnerships. Keys to the success of school-community partnerships include 1) communication, 2) shared decision 
making, 3) shared resources, 4) expertise and credibility, 5) sufficient time to develop and maintain relationships, 6) champions, 7) being present, 8) flexibility, 9) shared orientation, and 10) recognition of other partners' priorities (Bosma et al., 2010; Lachman \& Wlodarczyk, 2011; Lee, Zhang, \& Yin, 2011; Monroe, Blackwell, \& Pepper, 2010; Sanders, 2012). These themes must be present for a PD partnered with the school and community to be successful. However, there is also a reciprocal relationship with growth and success of the PD and partnership relationship. For example, communication between these entities must be present for success; thus, as the relationship grows and benefits are recognized for enhanced quality of education the communication avenues are nurtured and strengthened.

\subsubsection{Research Evidence on PD and School Community Partnerships}

Even though prior research provides evidence about effectiveness and stakeholders' perceptions on topics of school-community partnerships and online PD separately, research evidence is lacking on PD delivered online by school-community partnerships.

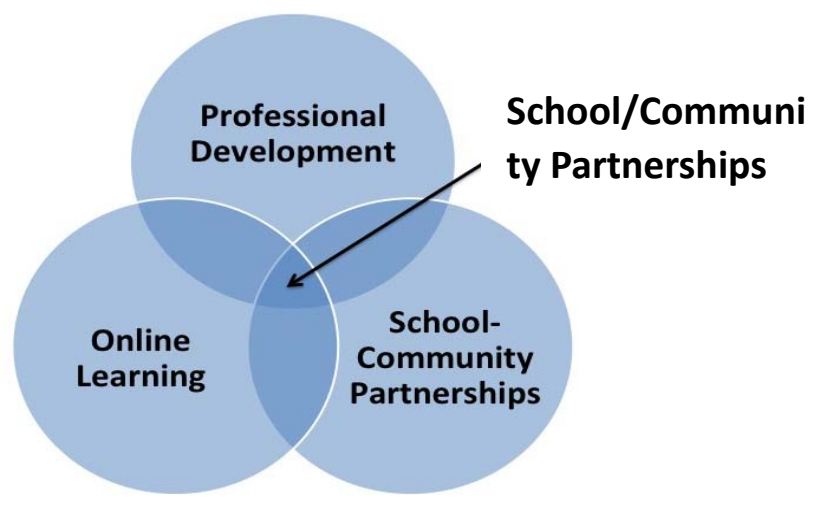

Figure 1. School/Community-Partnered Online PD for Teachers: Shared Focus

Figure 1 is a summary of three topics from the research literature.. These three topics afforded a balanced foundation to support the present study. The balanced foundation is complemented by a layer of research, which specifically targets the topic of online PD delivered through school-community partnerships. Findings from this research could guide the development of school-community partnerships and provide direction in their effective implementation.

\section{Purpose of Research}

The present study merged online PD with school-community PD partnerships and conducted multiple assessments of teachers' perceptions of this merger in an online professional development activity. Data were collected from 32 teachers using mixed methods to investigate their perceptions of engagement and usefulness of online professional development (PD) offered through a school-community partnership with National Aeronautics and Space Administration (NASA). The partnership between multiple school districts nationwide and NASA made available to the teachers an online Science, Technology, Engineering and Mathematics (STEM) PD course called MicroGX. The multiple and inter-related goals of the study were to identify, assess, and report teachers' perceptions of 
online PD delivered by school-community partnerships (see Figure 1). Results of the study could offer guidance in the successful development of future online PD delivered by school-community partnerships. The following research questions were designed to identify, assess, and report teachers' perceptions of online PD delivered by school-community partnerships:

(1) What are teachers' levels of active engagement in the PD-partnerships?

(2) What are teachers' perceived levels of satisfaction of the activities?

\section{Methodology}

The study involved an interactive, online PD delivered by school-community partnerships for grades K-12 schools nationwide and the National Aeronautics and Space Administration (NASA).At no cost to schools, NASA delivers online PD to multiple school districts nationwide via multiple programs and courses. One such course the Microgravity experience (MicroGX) was selected for this study based on numerous characteristics including a continuous timeline that provided engagement in online and school-community based activities and a manageable number of participants.

\subsection{Subjects}

Subjects in this study were teachers who participated in the NASA MicroGXPD course from March - October 2013. Participants were informed about the study during synchronous MicroGX webinars. All subjects received an information page and an informed consent form. Declining to participate in the research study did not have any impact on their participation in the MicroGX experience. The 32 participants were located at various school districts around the United States.

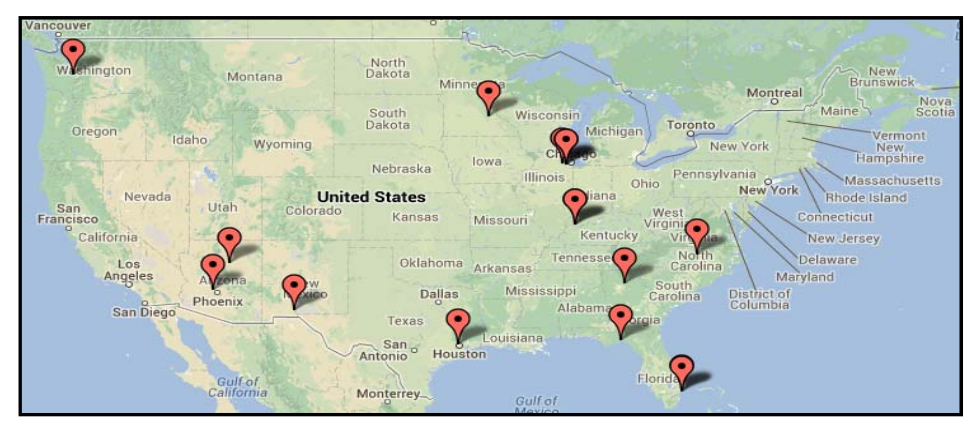

Figure 2. Sites across the United States for teachers participating in the study

Figure 2 identifies each of the site locations for the study. As illustrated in Figure 2, school locations reflected a broad distribution. These sites enabled us to have wide-ranging school district participation and to investigate the PD efficacy across a diversity of settings. 


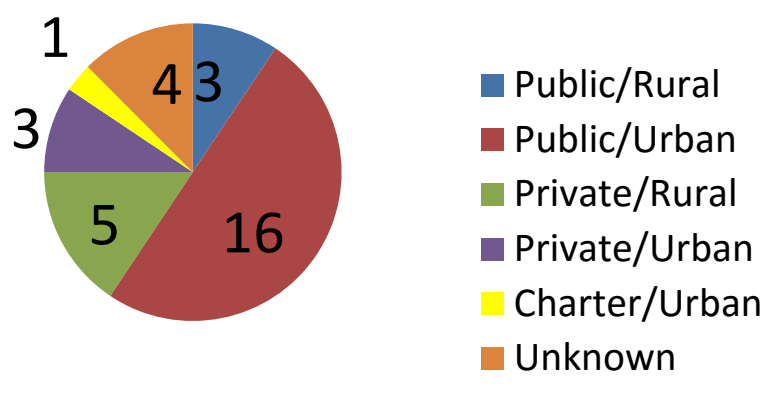

Figure 3. School types and location settings of teachers

The pie chart in Figure 3 presents the school types and school settings for the subjects. Not only did participants come from schools across the USA, they also came from a range of school types and school setting. Types of schools were public, private and charter. Settings ranged from rural to urban, with 8 teachers coming from rural and 20 teachers teaching in urban schools ( $4=$ no response).Participants represented every grade level between kindergarten and twelfth grades. The largest representation of grade levels occurred at the middle school level. Ten of the teachers taught sixth grade, eight taught seventh grade, and seven taught eighth grade. Many of the teachers taught multiple grade levels.

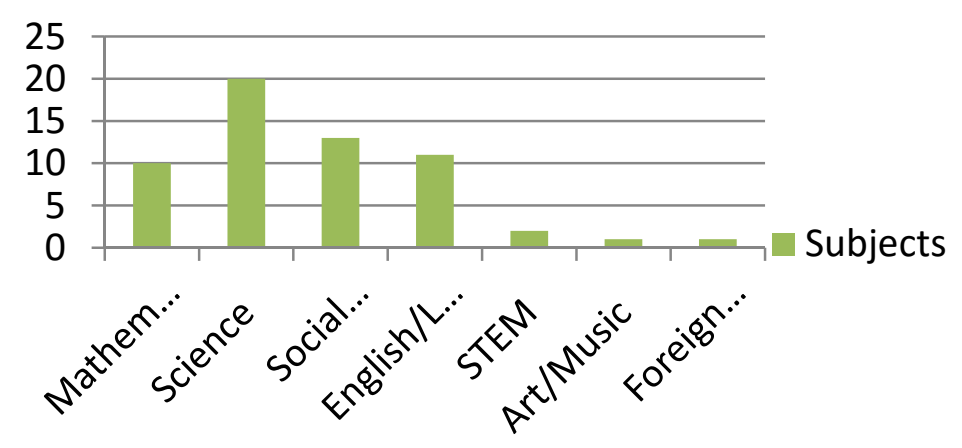

Figure 4. Content areas taught by teachers

Figure 4 provides a breakdown of content taught by the subjects.

Teachers were from content areas that included mathematics, science, social studies, English/language, STEM, art/music, and foreign language. A majority of the teachers taught science $(\mathrm{N}=20)$. Individual teachers, especially at the elementary school level, taught multiple content areas.

\subsubsection{PD Components}

As noted earlier in Figure 2, the PD occurred at school districts in multiple locations across the United States. Subjects participated in NASA's MicroGX PD via the Desire2Learn online learning community software. One week of PD took place in the NASA Education Office at NASA Johnson Space Center in Houston, Texas for face-to-face interactions in July 2013.The MicroGX content provided teachers with PD on the topic of microgravity, including principles of engineering design and inquiry processes. The goal of the PD was to 
help teachers prepare students for science, technology, engineering, and mathematics (STEM) based careers.

NASA's Teaching from Space Office and the Reduced Gravity Education Flight Program presentedK-12 educators an opportunity to take part in the Micro Gravitye Xperience (Micro GX) project. Teachers selected for the project were provided an opportunity to work collaboratively in developing experiments to be tested aboard a microgravity aircraft. Seven teams of four to five educators from a single school or school district participated in Micro GX. NASA personnel (one of the authors) worked directly with teachers through a series of Web seminars to initiate experiment development. Culmination of the online PD was to travel to NASA's Johnson Space Center in Houston, Texas, and participate in the Reduced Gravity Education Flight Program. Educator teams, including their students proposed and developed reduced-gravity experiments; received professional online development focusing on resources for microgravity; collaborated weekly with a NASA mentor; and experienced a reduced-gravity flight. Teachers performed custom experiments in a reduced-gravity environment. The online course continued with activities beyond the flight experience.

The online PD used Desire2Learn software. This software is conducive to creating a community of learners through the utilization of a multitude of features. For example, teachers could at anytime during online PD, interact with one another using discussion boards, interact with the researchers using chat rooms, send and receive emails, conduct collaborative exchanges, and utilize archived resources and information that were available on demand. This virtual environment in combination with direct experiences at the NASA site constituted the ongoing features of the PD.

\subsubsection{Data Collection}

Mixed methods were used to collect and analyze data (Creswell, 2007). Three data collection strategies were utilized to provide reliability and assure validity of the study. Data were collected using observations, surveys, and document analyses. Pseudonyms were used for teachers participating in the observations and document analyses. Surveys were conducted anonymously. Observations were collected during synchronous and archived MicroGX webinars. Document analyses included experiment design documents, discussion board posts, and news/print media articles about the 2013 MicroGX course experiences. 
NASA Office of Education Performance and Measurement Survey

Type of institution you teach at (circle all that apply):

Public Parochial Private Charter Rural Suburban Urban Other (specify)

What is (are) the grade(s) of students that you teach? (Check all that apply)

$\square \mathrm{K} \square 1 \square 2 \square 3 \square 4 \square 5 \square 6 \square 7 \square 8 \square 9 \square 10 \square 11 \square 12$

What is (are) the subject matter(s) that you teach? Check all that apply.

$\square$ Art/Music $\square$ Drama $\square$ Engineering $\square$ English/Language Art

$\square$ Foreign Language $\square$ Guidance $\square$ Health $\square$ Media Specialist/Library

$\square$ Mathematics $\square$ Physical Fitness $\square$ Science $\square$ Social Studies $\square$ Technology

$\square$ Other. Please specify

To what extent do you agree with the following statements? (Circle one)

1. This NASA experience has inspired me to bring NASA content into my classroom.

Strongly Agree Agree Neutral Disagree Strongly Disagree

Figure 5. (continued)

2. I can immediately apply what I learned from this NASA experience to my teaching about science, technology, engineering, and mathematics (STEM).

Strongly Agree Agree Neutral Disagree Strongly Disagree

Figure 5. (continued)

3. I will be more effective in teaching STEM concepts introduced in this NASA experience.

Strongly Agree Agree Neutral Disagree Strongly Disagree

4. Based on my NASA experience, I will make changes to my teaching activities. 
Strongly Agree Agree Neutral Disagree Strongly Disagree

5. Which activities do you plan to add or change to your teaching practices? (Check all that apply)

$\square$ Use printed materials presented at my NASA experience.

$\square$ Use subject matter covered at my NASA experience.

$\square$ Use technology resources introduced at my NASA experience.

$\square$ Use web resources presented at my NASA experience.

$\square$ Use teaching techniques presented at my NASA experience.

$\square$ Other. Please specify:

To what extent do you agree with the following statements? (Circle one)

6. The NASA materials used in this experience align well with what I teach.

Strongly Agree Agree Neutral Disagree Strongly Disagree

7. These resources will be effective in increasing my students' interest in STEM topics.

Strongly Agree Agree Neutral Disagree Strongly Disagree

8. This NASA experience provided ideas for encouraging student exploration, discussion and participation.

Strongly Agree Agree Neutral Disagree Strongly Disagree

9. I received activities, ideas or resources that could be used to involve families in their children's STEM education. 
Strongly Agree Agree Neutral Disagree Strongly Disagree 2016, Vol. 6, No. 2

10. I plan to use the family ideas suggested.

Strongly Agree Agree Neutral Disagree Strongly Disagree

11. I think the resources suggested will be effective with families.

Strongly Agree Agree Neutral Disagree Strongly Disagree

Figure 5. NASA OEPM Teacher Survey

An existing NASA Office of Education Performance and Measurement (OEPM) survey was used to obtain baseline data and subject demographics. Data analyses were conducted on the responses to the survey questions.

\subsubsection{Data analyses}

Questions were analyzed using open coding. Open coding is a free-coding process in which researchers develop and use a coding scheme to classify or manage data. This process involved examining in detail the data gathered and identifying, categorizing, and classifying the patterns (Patton, 2002). After the use of open coding techniques, analytic statements were used to further examine data. The open coding approach was based on a technique demonstrated by Emerson, Fretz and Shaw (1995) in which ethnographers, following the open coding process, make marginal notes on their data, which can be used to identify related or unrelated information. Open coding and analytic statements allowed the researchers to identify themes in the data set. Themes were identified by searching for like statements across responses by the participants. Lessons learned were interpreted and reported during the final phase of analyses (Lincoln \& Guba, 1985).

\section{Results}

Observations of the MicroGX course, completion of two surveys for all teachers, and document analyses were conducted to obtain data related to:

(1) What are teachers' level of engagement in the PD-partnerships' activities?

(2) What are teachers' perceived levels of satisfaction and dissatisfaction with components of PD- partnership activities?

The analyses of teachers' responses to the NASA survey provided insights into the impact the PD had on their STEM classroom instruction. 
Table 1. NASA Survey Results

\begin{tabular}{|c|c|c|c|c|c|c|}
\hline Questions & $\begin{array}{l}\text { Strongly } \\
\text { Agree } \\
\text { (5) }\end{array}$ & $\begin{array}{c}\text { Agree } \\
\text { (4) }\end{array}$ & $\begin{array}{c}\text { Neutral } \\
\text { (3) }\end{array}$ & $\begin{array}{c}\text { Disagree } \\
\text { (2) }\end{array}$ & $\begin{array}{l}\text { Strongly } \\
\text { Disagree } \\
\text { (1) }\end{array}$ & Total \\
\hline $\begin{array}{l}\text { Question } 1 \\
\text { This NASA Experience has inspired me } \\
\text { to bring NASA content into my } \\
\text { classroom. }\end{array}$ & $\begin{array}{c}28 \times 5= \\
140\end{array}$ & $\begin{array}{c}4 \times 4= \\
16\end{array}$ & 0 & 0 & 0 & 156 \\
\hline $\begin{array}{l}\text { Question } 2 \\
\text { I can immediately apply what I learned } \\
\text { from this NASA experience to my } \\
\text { teaching about STEM. }\end{array}$ & $\begin{array}{c}26 \times 5= \\
130\end{array}$ & $\begin{array}{c}3 \times 4= \\
12\end{array}$ & $\begin{array}{c}3 \times 3= \\
9\end{array}$ & 0 & 0 & 151 \\
\hline $\begin{array}{l}\text { Question } 3 \\
\text { I will be more effective in teaching } \\
\text { STEM concepts introduced in this } \\
\text { NASA experience. }\end{array}$ & $\begin{array}{c}26 \times 5= \\
130\end{array}$ & $\begin{array}{c}4 \times 4= \\
16\end{array}$ & $\begin{array}{c}2 \times 3= \\
6\end{array}$ & 0 & 0 & 152 \\
\hline $\begin{array}{l}\text { Question } 4 \\
\text { Based on my NASA experience, I will } \\
\text { make changes to my teaching activities. }\end{array}$ & $\begin{array}{c}19 \times 5= \\
95\end{array}$ & $\begin{array}{c}13 \times 4 \\
=52\end{array}$ & 0 & 0 & 0 & 147 \\
\hline $\begin{array}{l}\text { Question } 6 \\
\text { The NASA materials used in this } \\
\text { experience align well with what I teach. }\end{array}$ & $\begin{array}{c}15 \times 5= \\
75\end{array}$ & $\begin{array}{c}12 \times 4 \\
=48\end{array}$ & $\begin{array}{c}4 \times 3= \\
12\end{array}$ & $\begin{array}{c}1 \times 2= \\
2\end{array}$ & 0 & 137 \\
\hline $\begin{array}{l}\text { Question } 7 \\
\text { These resources will be effective in } \\
\text { increasing my students' interest in } \\
\text { STEM topics. }\end{array}$ & $\begin{array}{c}23 \times 5= \\
115\end{array}$ & $\begin{array}{c}5 \times 4= \\
20\end{array}$ & $\begin{array}{c}4 \times 3= \\
12\end{array}$ & 0 & 0 & 147 \\
\hline $\begin{array}{l}\text { Question } 8 \\
\text { The NASA experience provided ideas } \\
\text { for encouraging student exploration, } \\
\text { discussion and participation. }\end{array}$ & $\begin{array}{c}24 \times 5= \\
120\end{array}$ & $\begin{array}{c}7 \times 4= \\
28\end{array}$ & $\begin{array}{c}1 \times 3= \\
3\end{array}$ & 0 & 0 & 151 \\
\hline $\begin{array}{l}\text { Question } 9 \\
\text { I received activities, ideas or resources } \\
\text { that could be used to involve families in } \\
\text { their children's STEM education. }\end{array}$ & $\begin{array}{c}13 \times 5= \\
65\end{array}$ & $\begin{array}{c}10 \times 4 \\
=40\end{array}$ & $\begin{array}{c}9 \times 3= \\
27\end{array}$ & 0 & 0 & 132 \\
\hline $\begin{array}{l}\text { Question } 10 \\
\text { I plan to use the family ideas suggested. }\end{array}$ & $\begin{array}{c}9 \times 5= \\
45\end{array}$ & $\begin{array}{c}11 \times 4 \\
=44\end{array}$ & $\begin{array}{c}11 \times 3 \\
= \\
33 \\
\end{array}$ & $\begin{array}{c}1 \times 2= \\
2\end{array}$ & 0 & 124 \\
\hline $\begin{array}{l}\text { Question } 11 \\
\text { I think the resources suggested will be } \\
\text { effective with families. }\end{array}$ & $\begin{array}{c}11 \times 5= \\
55\end{array}$ & $\begin{array}{c}9 \times 4= \\
36\end{array}$ & $\begin{array}{c}11 \times 3 \\
= \\
33\end{array}$ & $\begin{array}{c}1 \times 2= \\
2\end{array}$ & 0 & 126 \\
\hline
\end{tabular}




\section{$\triangle 1$ Macrothink}

NASA survey results regarding the impact of PD on teachers' likely use of STEM acquired knowledge in their classroom instruction are summarized in Table 1. The number of teachers was totaled and the number of teachers was multiplied with score value to obtain a total score. For example in Table 1, total score for question 1 (156) was derived by multiplying 28 subjects who responded to strongly agrees by the value of $5 \times 28=140$, added to 4 subjects who responded to agree by the value of $4 \times 4=16$ resulting in a total of 156 .

Participants responded to an open-ended question in addition to taking the NASA survey. This question enabled the teachers to respond individually onthe fit of the PD experience with their curriculum and teaching. Researchers analyzed responses in terms of fit with participant's STEM curriculum and instruction. Analyses were based on agreement among four researchers that the statement would be categorized as a science, technology, math, or engineer term; rater agreement had to be $100 \%$.

Table 2. Responses and analyses of PD content fit with teachers' curriculum

\begin{tabular}{|l|l|}
\hline $\begin{array}{l}\text { Subject Responses to Question: How Did the NASA PD Connect } \\
\text { With Your Curriculum? }\end{array}$ & $\begin{array}{l}\text { Researcher analysis on } \\
\text { whether or not experience } \\
\text { connected with subject's } \\
\text { curriculum }\end{array}$ \\
\hline "Inquiry and scientific method and real world applications" & Yes \\
\hline "It didn't...I teach early American History" & Yes \\
\hline $\begin{array}{l}\text { "Bring more science into choir. Sounds, vibrations, pitches. Science } \\
\text { is everywhere." }\end{array}$ & Yes \\
\hline "Engineering and design. Astronomy. Real life experiences." & Yes \\
\hline "Magnets." & Yes \\
\hline $\begin{array}{l}\text { "Not directly connected to my biology curriculum, however great } \\
\text { example of experimental design." } \\
\text { "Content did not relate, but the inquiry process did. The experience } \\
\text { covered." }\end{array}$ & Yes \\
\hline "Scientific process. Experiment design. Scientific investigations." & Yes \\
\hline "International relations in space and on Earth." & Yes \\
\hline "Involving STEM topics." & Yes \\
\hline "Climate including tornadoes." & Yes \\
\hline "Absorbency, pollution, forces, gravity." & Yes \\
\hline "Classification and characteristics of water." & Yes science standards related to sound, amplitude, frequency \\
\hline
\end{tabular}




\begin{tabular}{|c|c|}
\hline $\begin{array}{l}\text { Subject Responses to Question: How Did the NASA PD Connect } \\
\text { With Your Curriculum? }\end{array}$ & $\begin{array}{l}\text { Researcher analysis on } \\
\text { whether or not experience } \\
\text { connected with subject's } \\
\text { curriculum }\end{array}$ \\
\hline \multicolumn{2}{|l|}{ Scientific design, testing, analyzing." } \\
\hline "Cohesion adhesion, surface tension, and capillary action" & Yes \\
\hline "Gravity" & Yes \\
\hline $\begin{array}{l}\text { "Not standards, but real life experiences with science and } \\
\text { engineering" }\end{array}$ & Yes \\
\hline "Convection" & Yes \\
\hline $\begin{array}{l}\text { "Nature of science including building models and conducting } \\
\text { experiments." }\end{array}$ & Yes \\
\hline "Nature of science and the properties of liquids." & Yes \\
\hline "Scientific and engineering process in real way." & Yes \\
\hline "Fluid dynamics." & Yes \\
\hline "Part of curriculum at all grade levels involved." & Yes \\
\hline "Observe matter in a variety of states." & Yes \\
\hline "Variable g environments and physics" & Yes \\
\hline "Research background for experiment" & Yes \\
\hline "Connected to lab in AP biology" & Yes \\
\hline "Dewey decimal system, research" & Yes \\
\hline
\end{tabular}

Table 2 presents the responses and analyses for responses to the prompt: How did this experience connect with your curriculum?

\subsection{Validity Check}

Participants' level of engagement is important in terms of determining the validity of their overall perceptions of satisfaction and dissatisfaction with PD activities. If we could not ascertain that teachers were highly engaged in the activities of professional development, then their responses for levels of satisfaction could be called into question. Answering the question about teachers' level of engagement in the PD-partnership activities utilized a wide source of data. The following data were collected by observing live and archived video web chats, discussion boards, and social media sites. Assignments submitted by teachers were also reviewed and documented. 


\subsubsection{Live Video Web Chats}

Nine randomly selected archived sessions from a total of 14 sessions of live video web chats were analyzed for attendance and participation. Analyses revealed that $69 \%$ of the participants attended the nine randomly selected video sessions. All participants' participated in five of the nine session. The same participant was never absent at any one of the analyzed web chat sessions, thus we felt secure in generalizing that at least $97 \%(31 / 32)$ of the teachers attended the web chat sessions offered in the PD.

\subsubsection{Discussion Board Engagement}

Participations in the discussion board over identified topics that were central to the PD were analyzed in order to determine participants' active involvement. There was a total of 10 discussion topics posted for all 32 participants. Five of these were required and each individually analyzed to determine level of involvement.

(1) Topic $=97 \%$ of participants posted and $91 \%$ of participants responded

(2) Topic $=97 \%$ of participants posted and $87 \%$ of participants responded

(3) Topic $=100 \%$ of participants posted and $94 \%$ of participants responded

(4) Topic $=91 \%$ of participants posted and $81 \%$ of participants responded

(5) Topic $=81 \%$ of participants posted and $53 \%$ of participants responded

There was a drop in participation below $90 \%$ for topic 5. This drop may have been due to timing. Topic 5 occurred toward the end of the assigned discussion activities and availability of teachers due to other school wide constraints was not taken into consideration. The average participation rate of 5 required topics including both post and response $=87 \%$. When Topic 5 is discarded the participation rate in posts and responses increases to $93 \%$. The teachers' rate of participation in discussion board activities highly supports active involvement in the PD activities.

\subsubsection{Assignment Completion}

Associated with the PD were 32 assignments that each participant had to complete. A measure of the total number of assignments that the group completed would be an indicator of their active engagement in the PD activities. Teachers completed $95 \%$ of the assignments. This high completion percentage was viewed as further support for active involvement in the professional development.

\subsubsection{Review of Existing Documents}

Existing documents were analyzed by reviewing news/print/media/articles, social media, and archived versions of teachers' final presentations and reports. Analyses of such documents would offer additional reflections of teachers' active PD involvement The type and frequency of documents were:

(1) News print/media/articles_-Sixteen published media articles were identified. 
(2) Social Media-Nine types of social media were identified and included Facebook pages, photo books, twitter feeds, and blogs.

The published articles and types of media were not a component of the PD. Participants' were either interviewed for a news print or other media sources and reported on their experiences. Social media occurrences for the PD were initiated by the participants and again were not a required component of the PD. Collectively, these examples of active engagement in the PD support the validity of responses we would obtain from the teachers reporting their perceptions of the efficient and inefficient features of the PD-partnership.

\subsubsection{Teachers' Perceived Benefits of PD Components}

The final, and perhaps the most important focus of this inquiry is whether or not the participants perceived the PD components beneficial to them in enhancing their quality of classroom STEM instruction? To provide insights and identify effective features of the PD, we analyzed the results from teachers' responses to a series of questions; the responses to questions that provided the most insight are presented Tables 3 and 4. 
Table 3. What attracted you to PD partnered with NASA?

Subject Responses

"The possibility in becoming part of a NASA project."

"NASA has a lot of opportunities for all types of teachers to participate in such events as these. As a language arts teacher, it allowed me to open up my classroom to science using grammar and writing."

"A science colleague at school."

"I thought it was a unique experience to be involved in as a teacher."

"Learned about it during another experience at NASA."

"The opportunity to work with NASA again."

"An experience I could share with my students and other teachers."

"Love of space."

"The opportunity to conduct my students' experiment in $0 \mathrm{~g}$."

"The potential to perform an experiment in microgravity and involve students in the engineering process."

"The connection with NASA for my students."

"The chance to learn more about NASA, to bring knowledge and experience back to my students, and of course to get to experience microgravity."

"I participated in this program 2 years ago and thought it would be very special to do it again."

"The opportunity to experience microgravity."

"The experience of travelling to Houston and experiencing microgravity."

"Getting as close to space without donning life support."

"My team lead sent out an email requesting volunteers for a unique experience with NASA."

"The chance to feel what weightlessness feels like while linking with student experiments and engineering designs. Plus, it's NASA!"

"I like that it required cooperation between a group of applicants and was focused on an interesting topic that I didn't have a lot of experience with."

"The idea of doing something unusual that could get my students excited."

"My fellow teacher asked me to participate."

"Our school is a NASA Explorer School, and the students at all grade levels enjoy learning about space. The idea of having our students help us design an experiment that we could test in zero g was appealing on multiple levels. We knew the students would be excited to partake in a project like this, and their enthusiasm was overwhelming."

"It was a once in a lifetime experience. To not only fly in microgravity, but also get to work with NASA. I think this experience really helped me inspire my students in the classroom." 


\section{Macrothink}

Table 3 reflects the teachers' responses to what attracted them to the NASA microGX PD. The acronym NASA is prevalent in the responses, for example ". . . work with NASA.”, ". . . it's NASA", and "The connection of NASA for my students". In addition, the microgravity experience appears often in statement such as, ". . . experiencing microgravity.", “. . . fly in microgravity", and "... opportunity to experience microgravity." 


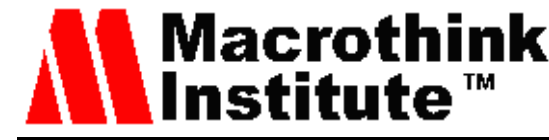

Table 4. What was the most beneficial feature of the PD

"The live chats $\mathrm{w} /$ microGX and personnel was helpful and informative. The info shared was useful in the classroom, as well as with preparation for the Houston experience."

"The many resources I was able to learn about and be able to bring back into my classroom."

"The ability to talk with interested parties live online. The NASA sites were incredible and all new to me. Very helpful and information was readily available."

"I thought the online community meetings every two weeks were very effective. I especially enjoyed learning from individuals who had already been through the program."

"I really enjoyed the live discussions and hearing what other teachers had to share. I learned a lot from others. Insider videos were cool."

"The NASA website."

"Video chats"

"The easy navigation and use was most effective for me with regards to the online PD."

"I enjoyed the special guests that taught us and gave us ideas about classroom experiments and speakers that gave us support during process."

"Bimonthly classes to get updates and learn about resources."

"The live discussion about what to expect in Houston. Very helpful-photos, PPT, information about what we needed to do."

"The live video class presentations."

"The knowledge of NASA resources and opportunities."

"I liked to learn about other ways that are used to create or simulate a weightless environment. It was nice to have someone to see and hear in person because during my previous MicroGX cycle we did not have any of this. I really think it has improved setting it up as a class."

The various video clips and lessons found online were the most effective for me-they allowed me to view them at my own pace, and was able to use quite a few of them for my students throughout the school year (and plan on using them in the future)."

"The online resources and learning about the equipment used to prepare the astronauts to live on ISS."

"It was nice to be able to see faces and names when presenting and having questions answered immediately instead of waiting for email response. The video calls were great to get to know the instructor."

"The live interactions with other teachers and their opinions and experiences that they brought to the table. It was great to be able to relate what we as adults were learning to what our students were learning and including them along the way."

"It was to know ahead of time what to expect and to have each step along the way made easy."

"The live interaction with participants allowing for questions and answers."

"Ways to incorporate teaching about gravity and microgravity in ways I could use it with elementary students"

"Live interaction with the other teams." 


\section{Macrothink}

Teachers' responses to the most beneficial PD features are reflected in Table 4. It is interesting to note that learning, either that of the teacher or the potential to take back to the classroom is pervasive throughout their responses. In addition, specific components of the PD that were valuable, such as video clips, video calls, structure about upcoming activities, and online community meetings were often mentioned.

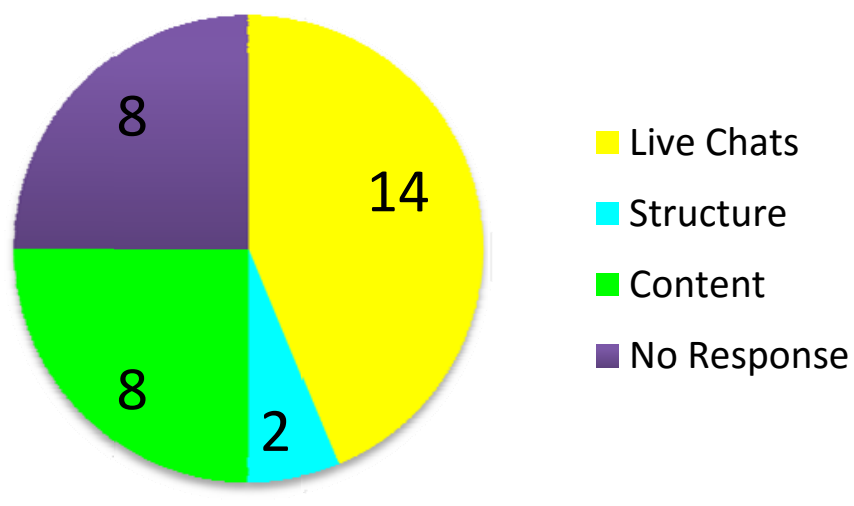

Figure 6. Summarized representation of most effective PD elements

A summarized visual of the teachers' identification of the most effective elements of the PD is presented in Figure 6. Approximately $50 \%$ of the most effective features were the live chats where teachers from different school districts and grade levels across the country interacted with each other. Almost equally perceived as effective were the structure and content of the PD.

Figure 6. Reported most effective components of the PD
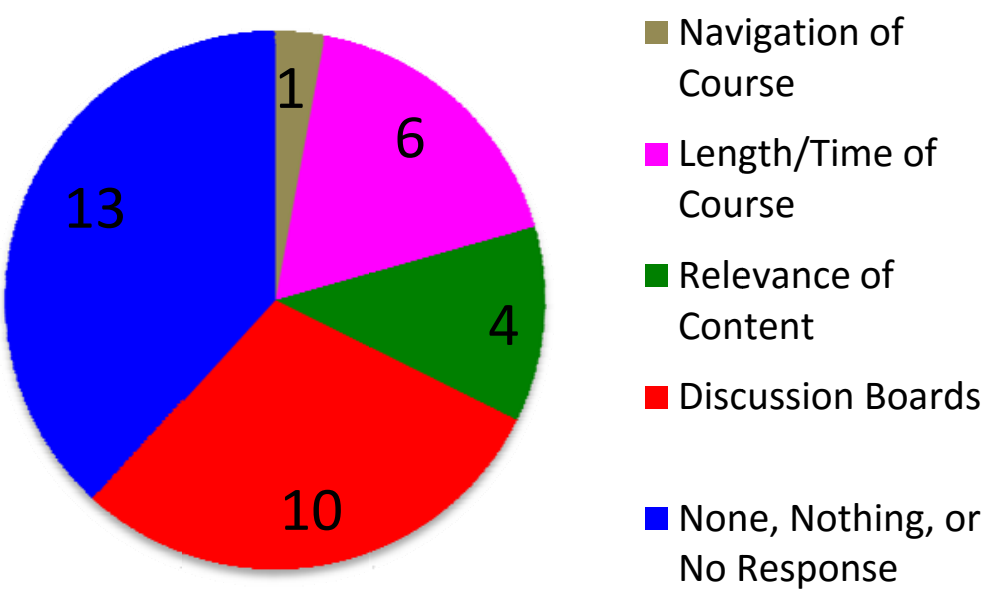

Figure 7. Teachers' perceived least effective features of the PD 
Figure 7 gives a visual representation of the least effective features of the PD. The pictorial view represents visually what participants' reported as the least effective features: discussion activities and factors of length (too long/time differences across the country and scheduling of the activities at inconvenient times) were the two major areas. In addition, since 4 participants $(+10 \%$ of sample) noted relevance of content as an issue of effectiveness, it should also be noted as a less effective feature.

In summary, this section provided an extensive overview of the methods implemented during the study, report on all data, and complete analyses.

\section{Conclusions}

A thorough analyse of data from two surveys, observations, and documents focused on answering the primary questions: 1) What are teachers' perceived levels of satisfaction and dissatisfaction with components fop- NASA partnership activities? Data from this study provide evidence that teachers 'perceptions of NASA's online STEM PD (MicroGX course) was positive, with many effective components. Furthermore, this positive perception is supported by their high level of PD engagement.

\subsection{Effective PD Components}

Overall, survey data show that the majority indicated the MicroGX course was a much more positive than negative experience. Teachers were initially attracted to the PD course because of the events offered, NASA's involvement, experiences with microgravity, influences from their colleagues, and impacts the PD would have on their instruction. All of participants indicated they would recommend this PD to other teachers. Collectively, participants were most satisfied with the interaction with others, resources, support, content, and content delivery. Ninety-seven percent of participants were satisfied with the PD. Ninety-four percent of them would participate in the PD again and would consider participating in more online PD offered by NASA. Effective components included content knowledge, student impact, resources, and support provided for their PD.

All teachers agree that this NASA-PD experience inspired them to bring STEM content into their classrooms, influenced them to make changes in their teaching activities; provided an ability to immediately apply what they learned from this experience to their teaching, and enhanced effectiveness in teaching STEM content. In addition, the majority felt that both on-line and face-to-face PD features connected directly to their curriculum. Furthermore, they sensed that shared resources could be effective in increasing their students' interest in STEM by employing the multiple ideas learned for encouraging students' exploration, discussion and participation in learning.

This PD presented teachers with a multitude of resources for use in teaching STEM topics. All of them felt that they would use these education resources in their future teaching and to involve families in their children's STEM education.

Observations during the PD online course and a review of interactive documents provide evidence that teachers were more engaged than disengaged in the PD. Additional indicators 
of participant engagement were: high attendance of live video chats, high percentage of completed assignments including final presentations, and participation in discussion boards and social media. A review of archived live video chats and final presentations reveal that teachers were not only engaged in this PD component, but also excited about its content. Other elements of the course appear to be positive as well, including interaction between teachers, interaction between teachers and instructors, and published media on the MicroGX course and experience.

Although prior research provides information on stakeholders' perceptions of school-community partnerships and online PD separately, there is a lack of existing research on PD delivered online by school-community partnerships. This study merged the two and completed an examination of teachers' perceptions of school/community-partnered online professional development. The goal of this study was to identify and assess teachers' perceptions that could reduce time and funding and aid in successful development of future online PD delivered by school-community partnerships. Additional expansion to online PD delivered by school-community partnerships and different types of community partners including state, federal government and non-profit organizations could build upon the existing data and further aid in narrowing the gap in existing research.

\section{References}

Avalos, B. (2010). Teacher professional development in Teaching and Teacher Education over ten years. Teaching and Teacher Education, 27(1), 10-20. http://dx.doi.org/10.1016/j.tate.2010.08.007

Barnett, M. (2002). Issues and Trends Concerning Electronic Networking Technologies for Teacher Professional Development: A Critical Review of the Literature. Paper presented at the American Educational Research Association, New Orleans, LA.

Bosma, L.M., Sieving, R.E., Ericson, A., Russ, P., Cavender, L., \& Bonine, M. (2010). Elements for successful collaboration between K-8 school, community agency, and university partners: The lead peace partnership. Journal of School Health, 80(10), 501-506. http://dx.doi.org/10.1111/j.1746-1561.2010.00534.x

Castle, S.R., \& McGuire, C.J. (2010). An analysis of student self-assessment of online, blended, and face-to-face learning environments: Implications for sustainable education delivery. International Educational Studies, 3(3), 36. http://dx.doi.org/10.5539/ies.v3n3p36

Chadwick, K.G. (2004). Improving schools through community engagement: A practical guide for education. Thousands Oaks, CA: Corwin Press.

Creswell, J.W. (2007). Qualitative inquiry and research design: Choosing among five approaches, (2nd Edition). Thousand Oaks, CA: Sage Publication.

Emerson, R.M., Fretz, R.I., \& Shaw, L.L. (1995). Writing Ethnographic Fieldnotes. University of Chicago Press, Chicago. http://dx.doi.org/10.7208/chicago/9780226206851.001.0001 
Fisher, J.B., Schumaker, J.B., Culbertson, J., \& Deshler, D.D. (2010). Effects of a computerized professional development program on teacher and student outcomes. Journal of Teacher Education, 61(302). http://dx.doi.org/10.1177/0022487110369556

Harlen, W., \& Doubler, S. (2004). Can teachers learn through inquiry online? Studying professional development in science delivered online and on-campus. International Journal of Science Education, 26(10), 1247-67. http://dx.doi.org/10.1080/0950069042000177253

Interactive Education Systems Design, Inc. (IESD) (2011). 2011 national survey on STEM education: $\quad$ Educator edition. Retrieved from http://mdcommonground.wikispaces.com/file/view/STEM_Report_11091

Lachman, A., \& Wlodarczyk, S. (2011). Partners at every level: From the classroom to the boardroom, consultants work toward district's goals. Journal of Staff Development, 32(1), 16-20.

Lee, J.C., Zhang, Z., \& Yin, H. (2011). A multilevel analysis of the impact of a professional development learning community, faculty trust in colleagues and collective efficacy on teacher commitment to students. Teaching and Teacher Education, 27(5), 820-830. http://dx.doi.org/10.1016/j.tate.2011.01.006

Lemke, C. (2012). Intel Teach: Jumpstarting 21st Century Learning. External evaluation by Metiri Group. Retrieved from http://http://download.intel.com/education/teach/public/IntelTeach_Jumpstarting21stcLearnin g_Paper.pdf

Lincoln, Y.S., \& Guba, E.G. (1985). Naturalistic inquiry. Beverly Hills, CA: Sage.

Matusov, E., Hayes, R.,\& Pluta, M.J. (2005). Using discussion webs to develop an academic community of learners. Educational Technology and Society, 8(2), 16-39.

Monroe, A.E., Blackwell, S.E., \& Pepper, S.K. (2010). Strengthening professional development partnerships while bridging classroom management instruction and practice. Professional Educator, 34(2), 18-26.

National Aeronautics and Space Administration (NASA) (2013). NASA's FY 2011 and FY 2012 annual performance plans. Retrieved January, 2013 from http://www.nasa.gov/pdf/533365main_NASAFY11_Performance_Plan-508.pdf

Patton, M. Q. (2002). Qualitative research and evaluation methods (3rd ed.). Thousand Oaks, CA: Sage Publications.

Sanders, M.G. (2012). Achieving scale at the district level: A longitudinal multiple case study of a partnership reform. Educational Administration Quarterly, 48(1), 154-186. http://dx.doi.org/10.1177/0013161X11417432

Sandholtz, J.H. (2002). Inservice training or professional development: Contrasting opportunities in a school/university partnership. Teaching and Teacher Training, 18(7), 815-830. http://dx.doi.org/10.1016/S0742-051X(02)00045-8 


\section{Macrothink}

Journal of Studies in Education

ISSN 2162-6952 2016, Vol. 6, No. 2

Schmidt, K. (2002). Classroom action research: A case study assessing students' perceptions and learning outcomes of classroom teaching versus online teaching. Journal of Industrial Teacher Education, 40(1), 45-59.

U.S. Department of Education. (2009). Race to the Top Program executive summary. Washington, D.C.: Retrieved from http://www2.ed.gov/programs/racetothetop/executive-summary.pdf

U.S. Department of Education, Office of Planning, Evaluation, and Policy Development (2010). Evaluation of Evidence-Based Practices in Online Learning: A Meta-Analysis and Review of Online Learning Studies. Retrieved from://www2http.ed.gov/about/offices/list/opepd/ppss/reports.html\#edtech 